\title{
PENGARUH PEMBERIAN LEAFLET TERHADAP PENGETAHUAN PENDERITA HIPERTENSI RAWAT JALAN DI RUMAH SAKIT SULTAN THAHA SAIFUDDIN KABUPATEN TEBO
}

\author{
Diana Tri Astuti, Eti Kurniawati, Cici Wuni \\ Sekolah Tinggi Ilmu Kesehatan Harapa Ibu Jambi \\ Email : dianatriastuti3@gmail.com
}

\begin{abstract}
ABSTRAK
Hipertensi yang tidak mendapat penanganan yang baik menyebabkan komplikasi seperti stroke, penyakit jantung koroner, diabetes, gagal ginjal dan kebutaan. Penyakit hipertensi yang ada di rawat jalan RSU Sultan Thaha Saifuddin pada tahun 2018 ke tahun 2019 mengalami peningkatan. Pada tahun 2017 jumlah pasien hipertensi di rawat jalan sebanyak 1328 kasus dan meningkat menjadi 1789 kasus pada tahun 2019. Penelitian ini menggunakan desain quasi eksperimen. Penelitian dilakukan di Rawat Jalan RS Sultan Thaha Saifuddin Kabupaten Tebo pada bulan Juli 2020. Sampel penelitian adalah pasien hipertensi rawat jalan RS Sultan Thaha Saifuddin sebanyak 20 orang. Teknik pengambilan sampel menggunakan teknik purposive sampling. Instrumen yang digunakan adalah leaflet dan kuesioner. Teknik pengumpulan data dengan pemberian leaflet dan kuesioner melalui wawancara. Data dianalsis menggunakan uji T Dependen. Hasil penelitian menunjukkan bahwa rata-rata pengetahuan responden sebelum diberikan leaflet sebesar 26,5 dan meningkat menjadi 30,9 setelah diberikan leaflet. Hasil bivariat diketahui ada pengaruh pemberian leaflet terhadap pengetahuan penderita hipertensi rawat jalan di Rumah Sakit Sultan Thaha Saifuddin Kabupaten Tebo Tahun $2020(\mathrm{p}=0,000)$. Diharapkan kepada rumah sakit untuk menyediakan leaflet, poster tentang hipertensi sehingga pasien hipertensi yang berobat jalan ke rumah sakit dapat membaca leaflet dan poster tersebut, sehingga dapat meningkatkan pengetahuan pasien tentang hipertensi
\end{abstract}

Kata Kunci $\quad$ : Pengetahuan, Leaflet, Hipertensi

\section{ABSTRACT}

Hypertension that is not treated properly causes complications such as stroke, coronary heart disease, diabetes, kidney failure and blindness. Hypertension in the outpatient services of the Sultan Thaha Saifuddin Hospital in 2018 to 2019 has increased. In 2017, there were 1328 outpatients with hypertension and increased to 1789 cases in 2019. This study used a quasiexperimental design. The study was conducted at the outpatient services at Sultan Thaha Saifuddin Hospital, Tebo Regency in July 2020. The sample of the study was 20 outpatient hypertension patients at Sultan Thaha Saifuddin Hospital. The sampling technique was using purposive sampling technique. The instruments used were leaflets and questionnaires. Data collection techniques by giving leaflets and questionnaires through interviews. The data were analyzed using the Dependent $T$ test. The results showed that the average respondent's knowledge before being given leaflets was 26.5 and increased to 30.9 after being given leaflets. The bivariate results showed that there was an effect of leaflet giving on 
the knowledge of outpatient hypertension patients at Sultan Thaha Saifuddin Hospital, Tebo Regency in 2020 ( $p=0,000)$. It is hoped that the hospital will provide leaflets and posters about hypertension so that hypertensive patients who go to the hospital can read these leaflets and posters, so as to increase patient knowledge about hypertension.

Keywords: Knowledge, Leaflet, Hypertension

\section{PENDAHULUAN}

Angka kejadian hipertensi di dunia termasuk masih sangat tinggi. Sekitar $20 \%$ populasi dewasa mengalami hipertensi, lebih dari $90 \%$ diantara mereka menderita hipertensi esensial (primer) yang berarti tidak dapat ditentukan penyebab medisnya. Sisanya mengalami kenaikan tekanan darah dengan penyebab tertentu (hipertensi sekunder) seperti penyempitan arteri renalis. Hipertensi esensial biasanya dimulai sebagai proses labil (intermiten) pada individu di usia dewasa yakni sekitar 30 tahun dan awal 50 tahun secara bertahap menetap ditubuh, suatu saat dapat menjadi mendadak dan berat (1).

Data Riskesdas tahun 2018 menunjukkan bahwa kejadian hipertensi sebesar 34,1\% (Kemenkes RI, 2018). Data kejadian hipertensi pada usia $\geq 18$ tahun di Provinsi Jambi pada tahun 2017 sebesar 25,15\%. Prevalensi kejadian hipertensi pada laki-laki sebesar $22,48 \%$ dan prevalensi kejadian hipertensi pada perempuan sebesar $27,30 \%$.

Hipertensi sering tidak menimbulkan gejala sehingga disebut sebagai silent killer, sementara tekanan darah yang terus menerus tinggi dalam jangka waktu lama dapat menimbulkan komplikasi. Hipertensi yang tidak mendapat penanganan yang baik menyebabkan komplikasi seperti stroke, penyakit jantung koroner, diabetes, gagal ginjal dan kebutaan. Stroke (51\%) dan penyakit jantung koroner (45\%) merupakan penyebab kematian tertinggi (Kemenkes RI, 2018).

Data Rumah Sakit Umum Sultan Thaha Saifuddin tahun 2019 menunjukkan bahwa penyakit tidak menular (PTM) tertinggi di rawat jalan adalah hipertensi (1.789 kasus), diabetes militus (964 kasus), penyakit sendi/artritis (672 kasus). Penyakit hipertensi yang ada di rawat jalan RSU Sultan Thaha Saifuddin pada tahun 2018 ke tahun 2019 mengalami peningkatan.

Pengetahuan tentang hipertensi berhubungan dengan pengendalian tekanan darah. Pengetahuan dan kesadaran pasien tentang hipertensi merupakan faktor penting dalam mencapai kontrol tekanan darah. Pengetahuan individu mengenai hipertensi membantu dalam pengendalian hipertensi karena dengan pengetahuan ini individu akan sering mengunjungi dokter dan patuh pada pengobatan. Pada hipertensi, pengetahuan dan sikap pasien bisa mempengaruhi 
kepatuhan, pengendalian tekanan darah, morbiditas dan mortalitas pasien.

Beberapa alasan yang berpengaruh pada kurangnya pengenalan dan kontrol pada hipertensi adalah kurangnya pengetahuan orang-orang mengenai berbagai macam aspek dari tekanan darah tinggi. Pengetahuan dan kesadaran pasien mengenai tekanan darah memegang peranan penting pada kemampuan untuk mencapai kesuksesan pengendalian tekanan darah pada hipertensi.

Salah satu cara untuk meningkatkan pengetahuan seseorang dengan memberikan informasi. Untuk memberikan informasi tersebut diperlukan beberapa media salah satunya adalah leafleat. Leaflet adalah produk dokumentasi dan komunikasi yang menyediakan pengenalan dan gambaran mengenai sebuah organisasi atau kegiatan. Sebuah leaflet bisa digunakan untuk mempromosikan LSM/organisasi berbasis masyarakat dengan kegiatannya, mempublikasikan layanan atau kegiatan, dan berkomunikasi dengan pesan, pesan yang spesifik berisi laporansingkat dan informasi yang jelas untuk menyediakan gambaran yang jelas dan sederhana ketimbang deskripsi yang mendetail.

Berdasarkan latar belakang tersebut maka peneliti melakukan penelitian tentang pengaruh pemberian leaflet terhadap pengetahuan penderita hipertensi rawat jalan di Rumah Sakit Sultan Thaha Saifuddin Kabupaten Tebo Tahun 2020.

\section{METODE}

Penelitian ini dilakukan dengan metode kuantitatif dengan desain quasi eksperimen untuk mengetahui pengaruh pemberian leaflet terhadap pengetahuan penderita hipertensi rawat jalan di Rumah Sakit Sultan Thaha Saifuddin Kabupaten Tebo Tahun 2020. Penelitian dilakukan di Rawat Jalan RS Sultan Thaha Saifuddin Kabupaten Tebo pada bulan Juli 2020. Sampel penelitian adalah pasien hipertensi rawat jalan RS Sultan Thaha Saifuddin sebanyak 20 orang. Teknik pengambilan sampel menggunakan teknik purposive sampling. Instrumen yang digunakan adalah leaflet dan kuesioner. Teknik pengumpulan data dengan pemberian leaflet dan kuesioner melalui wawancara. Data dianalsis menggunakan uji $\mathrm{T}$ Dependen.

\section{HASIL PENELITIAN}

Hasil analisis univariat menunjukkan rata-rata pengetahuan responden sebelum diberikan leaflet sebesar 26,5 dan meningkat menjadi 30,9 setelah diberikan leaflet (Tabel 1)

Hasil analisis bivariat menunjukkan bahwa ada pengaruh pemberian leaflet terhadap pengetahuan penderita hipertensi rawat jalan di Rumah Sakit Sultan Thaha Saifuddin Kabupaten Tebo Tahun $2020 \quad(p=0,000) \quad($ Tabel 2). 
Tabel 1. Rata-rata pengetahuan Responden Sebelum dan Setelah Diberikan di Ruang Rawat Jalan Rumah Sakit Sultan Thaha Saifuddin Kabupaten Tebo

\begin{tabular}{lcccc}
\hline \multicolumn{1}{c}{ Pengetahuan } & Mean & SD & Minimum & Maksimum \\
\hline Sebelum diberikan leaflet & 26,5 & 1,906 & 22 & 29 \\
Setelah diberikan leaflet & 30,9 & 1,294 & 29 & 33 \\
\hline
\end{tabular}

Tabel 2 Pengaruh Pemberian Leaflet terhadap Pengetahuan Penderita Hipertensi Rawat Jalan di Rumah Sakit Sultan Thaha Saifuddin Kabupaten Tebo

\begin{tabular}{lccc}
\hline \multicolumn{1}{c}{ Pengetahuan } & N & Rata-rata & p-value \\
\hline Sebelum diberikan leaflet & 20 & 26,50 & 0,000 \\
Setelah diberikan leaflet & 20 & 30,90 & \\
\hline
\end{tabular}

\section{PEMBAHASAN}

Berdasarkan hasil penelitian diperoleh nilai $\mathrm{p}=0,000$, sehingga dapat disimpulkan bahwa ada pengaruh pemberian leaflet dengan pengetahuan pada penderita hipertensi rawat jalan di Rumah Sakit Sultan Thaha Saifuddin Kabupaten Tebo Tahun 2020.

Hasil penelitian ini sejalan dengan penelitian yang dilakukan oleh Nursi Susanti, et al (2017) di Puskesmas Serasan yang menunjukkan bahwa terdapat perubahan pengetahuan lansia yang sudah diberikan leaflet, dan leaflet efektif terhadap pengetahuan penderita hipertensi di Puskesmas Serasan Kabupaten Natuna dengan nilai pvalue $=0,000<0,05$. Hasil penelitian Isadora Rahmawati, et al (2018) di Puskesmas Kota Yogyakarta diperoleh hasil bahwa dengan pemberian leaflet hipertensi dapat meningkatkan pengetahuan dan kepatuhan pada pasien hipertensi di Puskesmas Kota Yogyakarta bagian barat.

Faktor-faktor yang mempengaruhi pengetahuan adalah tingkat pendidikan, informasi, budaya, pengalaman dan sosial ekonomi (Notoatmodjo, 2012). Pemberian informasi secara formal maupun nonformal dapat meningkatkan pengetahuan. Pemberian media leaflet merupakan salah satu pemberian informasi non formal yang sering digunakan dalam pendidikan kesehatan. Leaflet merupakan selebaran kertas yang dapat dilipat-lipat, berisi tulisan cetak dan beberapa gambar tertentu tentang suatu topik khusus untuk sasaran dan tujuan tertentu (Notoatmodjo, 2007).

Sesuai dengan pendapat Adisusilo (2010), untuk memberikan informasi dibutuhkan salah satu media yaitu leaflet. Kegunaan dan keunggulan leaflet adalah sederhana dan sangat murah, orang dapat menyesuaikan dan belajar mandiri, 
pengguna dapat melihat isinya pada saat santai, informasi dapat dibagikan dengan keluarga dan teman. Leaflet juga dapat memberikan detil (misalnya statistik) yang tidak mungkin bila disampaikan lisan.

Media leaflet dapat diperoleh dengan mudah serta efektif digunakan sebagai media informasi. Sebagai media informasi, gambar dan foto haruslah dipilih atau digunakan sesuai dengan tujuan yang telah ditetapkan. Dengan adanya gambar atau foto dapat membangkitkan motivasi dan minat untuk membantu menafsirkan serta mengingat pesan yang berkenaan dengan gambar atau foto tersebut (Notoatmodjo, 2007).

Menurut penelitian Subarjah (2011), diperoleh hasil sebanyak $67 \%$ leaflet efektif dalam mempengaruhi perilaku seseorang. Penelitian Setiana (2006), diperoleh hasil $70 \%$ keefektivitasan leaflet dipengaruhi oleh pesan gambar yang disampaikan didalam leaflet. Efektifitas merupakan sesuatu yang memiliki pengaruh atau akibat yang ditimbulkan, manjur, membawa hasil dan merupakan keberhasilan dari suatu usaha atau tindakan.

Hasil penelitian menunjukkan bahwa ada pengaruh antara pemberian leaflet tentang dengan pengatahuan pada penderita hipertensi. Hal ini disebabkan karena isi leaflet mudah dipahami oleh responden. Isi leaflet terdapat gambar yang membuat minat responden melihat dan membaca isi leaflet tersebut. Selain itu, waktu yang tersedia untuk membaca leaflet tersebut adalah 5-10 menit. Hal tersebut lebih dari waktu yang dibutuhkan untuk membaca leaflet sekali, sehingga responden dapat membaca lebih dari satu kali dan dapat lebih memahami materi leaflet.

Untuk itu diharapkan kepada petugas kesehatan baik di Puskesmas atau Rumah Sakit untuk memberikan edukasi tentang hipertensi dengan menggunakan media leaflet kepada masyarakat sehingga pengetahuan masyarakat tentang hipertensi meningkat

\section{KESIMPULAN DAN SARAN}

Berdasarkan hasil penelitian diketahui bahwa ada pengaruh pemberian leaflet terhadap pengetahuan penderita hipertensi rawat jalan di Rumah Sakit Sultan Thaha Saifuddin Kabupaten Tebo

Diharapkan kepada rumah sakit untuk menyediakan leaflet, poster tentang hipertensi sehingga pasien hipertensi yang berobat jalan ke rumah sakit dapat membaca leaflet dan poster tersebut, sehingga dapat meningkatkan pengetahuan pasien tentang hipertensi

\section{DAFTAR PUSTAKA}

1. Brunner, Suddarth. Buku Ajar Keperawatan Medikal Bedah Edisi 8. Jakarta: EGC; 2013.

2. Kemenkes RI. Riset Kesehatan Dasar Tahun 2018. Jakarta: Kemenkes RI; 2018.

3. Dinkes Provinsi Jambi. Profil 
Kesehatan Provinsi Jambi Tahun 2017. Jambi: Dinas Kesehatan Provinsi Jambi; 2018.

4. Kemenkes RI. Profil Kesehatan Indonesia Tahun 2017. Jakarta: Kemenkes RI; 2018.

5. Oliveria SA, Chen RS, McCarthy BD, Davis CC, Hill MN. Hypertension Knowledge, Awareness, and Attitudes in a Hypertensive Population. J Gen Intern Med. 2004;20:219-25.

6. M Alexander, Gordon NP, Davis CC, R S Chen R.S. Patient Knowledge and Awareness of Hypertension Is Suboptimal: Results From a Large Health Maintenance Organization. J Clin Hypertens. 2003;5:254-60.

7. Elhadi IE. Identifi cation of Factors Affecting Blood Pressure Control in Patients Admitted with Hypertension in Penang General Hospital. 2007.

8. Busri OA. Impact of Patients' Knowledge, Attitude and
Practices on Hypertension on Compliance with Antihypertensive Drugs in a Resource-poor Setting. TAF Prev Med Bull. 2010;9(2):8792.

9. A J Viera, Cohen LW, Mitchell MC, Sloane PD. High Blood Pressure Knowledge Among Primary Care Patients with Known Hypertension: A North Carolina Family Medicine Research Network (NC-FM-RN) Study. J Am Board Fam Med. 2008;21:300-8.

10. Ragot S., Sosner P., Bouche G., Guillemain J. HD. Appraisal of the Knowledge of Hypertensive Patients and Assesment of the Role pf the Pharmacists in the Management of Hypertension: Results of a Regional Survey. J Hum Hypertens. 2005;19:57784.

11. Notoatmodjo S. Promosi Kesehatan dan Ilmu Perilaku. Jakarta: Rineka Cipta; 2007. 